\title{
ADALET VE TIP
}

Yazan: Dr. Cahit OZEN

Adalet sosyal ve medenî hayatın temelidir. Hukukun güicì, cemiyetin huzurudur. Adalet insanlarm cemiyet göreneklerine uymayan aksiyon ve reaksiyonları üzerinde muhakeme yapar ve karar verir. Bu karar ve hükmün objektif delillere istinat etmesi istenir. Bunun için de fennin her şubesinden istifade imkânları araştırılır. Bunların başında da tıp gelir. Adalet her bilim dalindan faydalanabilir. Adlî Tıp da tıbbın bütün açıklı̆̆ı ile meydana çıkmasına yardım eder. Adlî tıp insanların en yüksek zihin melekelerinden, onlamn çürümüş, toprak olmuş en küçük bakiyelerine kadar tedkik eder. Thp'da muayene, teşhis ve tedavi yerine hukukta muhakeme, karar ve infaz vardir. Yani organik bir marazın teşhis ve ona bir çare bulunma yanında, sosyal bir marazın meydana çkarılması ve zarar görenin tatmin edilmesi gelir. Adalet islahına imkân göremeđiği marazî ifna dahi eder. Thpda bu kadar ileri gidilmediği ve iyileşmiyecek bir hastanın öldürülmesi (euthonasia) uygun görülmemektedir.

Bir suçlunun idamı keyfiyeti de her zaman mïnakaşalara yol açmaktadir.

Hukuk ve tıbbın metodlam arasında bazı aynlıklar da vardır. Hukuk, kanunlara bağlı ve Stable'dir, tıp ise hareketli ve dinamiktir.

Adaletde tıbbın rolü oldıkça geniştir, bilhassa ceza hulkuku adlî tıbbın büyük mikyasta yardımına muhtaçtır. Bazı defa tıbbın yardımı olmadan adalet hükmïnü veremez. $O$ halde tıp adaletin hükmüne iştirak eder.

Adlî tıb, tıbbın her tekâmüliıinden adalete yararı taraflam çlkarmaktadir. Son ynllarda tip sahasindaki ilerlemeler antibiotikler ve proteinlerin izolasyonu istikametindedir. Her hayvan cinsine ait proteinle. rin kan gruplam gibi muhtelif gruplar halinde aymlması ve bunlamn adetlerinin ve çesitlerinin çoğalması sayesinde bu gün, kan, meni, tükrük, cerahat, idrar gibi insanlara ait lekelerden şahıslamn hüviyetlerini tesbite, babalığın tâyininde istifade edilmektedir. Meselâ bir sıgara izmaritinin iłzerindeki tükrükten sahibine ait bazı hususiyetler söylenebiliyor. En 
dakik laboratuvar çalışmalarında, mikrimetodlarla yapılan bu araştırmalar bugün adlî tıpda günlük işler arasına girmiştir.

Adli tup fizik ve kimyadaki yeniliklenden istifade yollarına giderek bugün toksikolojide şimik analizler gibi specral analizler de yapmaktadır. Modern toksikoloji laboratuvarlannda spectrograflar, bir zehirlenme vakasında zehirin ne olduğunu pek kisa bir zamanda kaydetmektedirler.

Akıl hastalıklarımn teşhisinde pozitif bir çalığma sahası açan elektro-ansefalogram'in adli tibba tatbikatı yapılmıs, bir akıl hastasının objektif teşhisi mümkün olabilmiştir. Ayni zamanda normal kimselerde aym aym grafikler veren bu alet sayesinde hivivet tesbiti bakımından is. tifade imkânları arastımlmaktadır.

Atom enerjisinin atom bombası şeklinde tatbik sahasına konması sonunda adlî tıp bu kuvvetin zararlarnn tedkik için faaliyete geçmiştir. Hiroshima ve Nagasaki'deki infilâklarda ölenlerin ve kalanların üzerinde bu balakımdan araştırmalar yapılmıştır.

Adî tıp, sahasimı sosyal tıbba doğru tevsi etmiş bulunuyor. Is kazalam, meslek ve is hastallklam ve bunlarda malûliyet derecesinin takdiri aktüel işler arasındadır. Bütün bu geniş işler sebebiyle adî̀ tıp içinde ayrıca psikiyatri, toksikoloji gibi ihtisas şubeleri belirmiştir. Modern adlî tip enstitülerinde doktorlar, kimyagerler, fizisiyenler is birliği yapmaktadırlar ve artık laboratuvarsız tek hekimin selâhiyetleri tahdit edilmiştir. Hekimler için geniş bir ihtisas şubesi olan adlî tıp bugün memleketlerde hukuk kültürü arasına da sokulmuştur, çünkü tıptan istifade imkânları ancak onun metodlarını bir dereceye kadar öğrenmekle mümkün olabilmektedir.

tngilterede cinayetierden maada kaza, intihar, ansızın ölümler, şüpheli ölümler ve ölümünden evvel bir doktor tarafından görülmemiş bütün ölüm vakalarnda, hastahanelerde ameliyattan sonra 24 saat içinde ölenlere otopsi yapłlir ve böyle vakalarda hukukî durumu tetkik eden "Coroner Court" denilen hususî mahkemeler vardır. Bu mahkemelerin hâkimleri (Coroner) çift selâhiyetlidir. Yâni hukuk ve tıp selâhiyetleri vardir. Ingiltere ve Wales eyaletinde 270 Coroner meveut olup bunlardan 10 tanesi hem hukuk ve hem tip fakültelerinden mezun olduktan sonra hâkim olmuşlardır. Hekimlik selâhiyeti olmayan Coroner'ler tıp fakültelerinde uzun müddet özel kurslara devam ederek geniş adî́ tıp bilgisi aldiktan sonra Coroner olabilmektedirler. Coroner mahkemeleri ve cinayet mahkemeleri (Criminal Court) içinde otopsi salonları ve ihtiyaca yeter adli tıp laboratuvarlan vardır.

Coroner mahkemeleri hâkimleri kendi sahalarındaki ölüm ve yaralanma vakialarm tetkik ve muhakeme ederken verilen raporlarn ve din- 
lenen șahitlerin anlattıklarını bir hâkim ve hekim gibi düşünerek icablna bakmaktadırlar. Bu mahkemelerde tıbbî şahadetler yapulırken Coroner doktorla münakaşa etmekte ve neticede vukufla bir karar verebilmektedir.

Görüldüğü gibi adalet tıbdan büyüik istifadeler sağlamakta ve tıbbın kazı kısımlarını mevzuu içine almış bulunmaktadırlar. Adalet diğer ilim ve bütün fen şubelerinden de istifade eder. Fakat bu çok mahduttur ve hiç bir zaman da hukukçu bu bilgileri kısmen olsun öğrenmeye lüzum hissetmez. Adalet sik sık tıbbm kararnna müracaat ettiği için tıp içerisinde adlî tıp denilen bir ihtisas şubesi aymlmıs ve bu bilim tıp kültürünün esas şubelerinden biri olmuştur.

Hekimlerin adlî tıp bilgilerile mücehhez yetişmeleri için bir çok medenî memleketlerde adlî vakaların muayeneleri yapılırken ve raporları yazllurken hekim talebesi bizzat bulunur ve hatta hocalarnin kontrolu altında bu muayeneleri yapar. Memleketimizde de tip talebesinin daha fazla adlî tıp bilgilerile kuvvetli yetişmesi için aymı şekilde adlî vakaları sık sık görmesi ve mahkemelerde adlî şahadet yapilurken bulunması gerelkmektedir. Kısaca izah edildiği üzere adaletin tıpla geniş ölçüde işbirliği yapması kendi metodlar icabıdır. 